УДК 004.8

\title{
ШТУЧНИЙ ІНТЕЛЕКТ: ПЕРСПЕКТИВИ ТА ТЕНДЕНЦІї РОЗВИТКУ
}

Пчелянський Д. П. ${ }^{1}$, Воінова $^{2}$ С. А.

Одеська національна академія харчових технологій, Одеса, Україна

Магістрант $^{1}$, к.т.н., доцент ${ }^{2}$

ORCID: ${ }^{2}$ http://orcid.org/0000-0003-0203-0599

E-mail: ${ }^{1}$ d.pchelyanskiy97z@gmail.com, ${ }^{2}$ voinova_s@yahoo.com

Copyright (C) 2018 by author and the journal “Automation technologies and business - processes. This work is licensed under the Creative Commons Attribution International License (CC BY). http://creativecommons.org/licanses/by/4.0

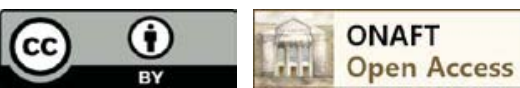

DOI:

Анотація. У статті подано основні дослідження в галузі штучного інтелекту як науки, щзо займається створенням автоматизованих інтелектуальних систем. Досліджено технологічні аспекти створення систем штучного інтелекту, розкрито різні підходи до їх конструювання. Показано місие експертних систем $i$ нейромережевих технологій у ицьому процесі. У статті розкрито сутність та уявлення про шттучний інтелект, який постійно змінюється, трансформується бачення шляхів його розвитку, підходи до вивчення та функціонування в цілому. Найбільи перспективними напрямками в пізнанні штучного інтелекту, є нейронні мережі, еволюиійні обчислення, експертні системи. Нейронні мережі здатні вирімувати такі прикладні задачі, як: фінансове прогнозування, контроль за діяльністю мереж, иифрування даних, діагностика систем. Розробка інтелектуальних експертних систем і нейронних мереж - це лише перші кроки на шляху до створення сильного штучного інтелекту. В межах иъього змінюються вимоги до сучасних інформаційних інтелектуальних систем.

У статті подано загальну картину розвитку різних напрямків штучного інтелекту шляхом аналізу європейських $i$ американських конференцій по штучному інтелекту за останні кілька років. Проаналізовано та надано статистичну інформацію за даними Німецької дослідницької компанї IPlytics про компанії, які лідирують в галузі штучного інтелекту. В статті наведено інформаџію про стан розвитку штучного інтелекту в Україні.

Abstract. The article presents the main studies in the field of artificial intelligence as a science that deals with the creation of automated intelligent systems. Investigated the technological aspects of creation of systems of artificial intelligence, reveals different approaches to their design. Shows the location of expert systems and neural network technologies in this process. The most promising areas in the knowledge of artificial intelligence are neural networks, evolutionary computing, expert systems. Neural networks are capable of solving such applied problems as: financial forecasting, monitoring network activities, data encryption, system diagnostics. The development of intelligent expert systems and neural networks are just the first steps towards creating strong artificial intelligence.

The article presents the general picture of development of artificial intelligence by analyzing the European and American conferences on artificial intelligence over the last few years. Presents statistical information according to German research company IPlytics about the companies leading in the field of artificial intelligence. The article presents information on the status of the development of artificial intelligence in Ukraine.

Ключові слова: штучний інтелект, нейронні мережі, експертні системи, робототехніка, автоматизовані інтелектуальні системи.

Keywords: artificial intelligence, neural networks, expert systems, robotics, automated intelligent systems.

\section{Вступ}

Штучний інтелект, як науковий напрямок, існує з середини ХХ століття. За останні роки становлення науки що займається розробкою автоматизованих інтелектуальних систем, сформувались концептуальні моделі та особисті методи і прийоми. Багато ідей штучного інтелекту реалізовано в спеціальних технологіях, які ввійшли в повсякденне життя.

Розробки інтелектуальних машин проводяться з метою інтенсифікації виробництва, створення помічників людини, розвитку медицини, будівництва та ряду інших галузей на новому рівні. 
В Україні штучний інтелект знайшов своє застосування в експертних системах для прогнозування економічних явищ; базах даних та знань у різних предметних областях.

Аналіз літературних даних і постановка проблеми

Незважаючи на досить широке висвітлювання у роботах науковців актуальності розвитку інформаційних інтелектуальних систем, їх ролі, перспектив, не достатньо уваги надається проблемам, які існують в цьому напрямку. Дослідженню штучного інтелекту присвятило себе багато світових та вітчизняних вчених: В. Піттс, Ф. Розенблатт, К. Цузе, В. Маккалок, М. Бондаренко, Т. Бровченко, М. Деркач, О. Карпов та інші.

Головною характеристикою інформаційних інтелектуальних систем $є$ націленість на вирішення конкретних інтелектуальних завдань. Проте дослідження розвитку штучних інтелектуальних систем стають все більш актуальними.

Мета і завдання дослідження

Дослідження штучного інтелекту зумовлена тим, що проблема розвитку автоматизованих інтелектуальних систем не мала стійкого характеру.

Уявлення про штучний інтелект постійно змінюються, трансформується бачення шляхів його розвитку, підходи до вивчення та функціонування в цілому. В межах цього змінюються вимоги до сучасних інформаційних інтелектуальних систем.

Штучний інтелект (AI) - це науковий напрям, в рамках якого ставляться і вирішуються задачі апаратного або програмного моделювання тих видів людської діяльності, які традиційно вважаються інтелектуальними.

Приклади використання штучного інтелекту - від комп'ютерів, що грають у шахи, до автономних роботизованих систем. Однак, на етапі свого сучасного прогресу вони істотно впливають на життєдіяльність всього суспільства.

До переліку інтелектуальних задач відносять: розпізнавання образів; аналіз ситуації; логічне мислення; розуміння нової інформації; навчання і самонавчання; планування цілеспрямованих дій.

Інтелектуальна система може припускати зовнішнє керування, але для неї характерною є самокерованість. Система має певну мету і прагне так планувати свої дії, щоб досягати цієї мети. Як вхідні стимули системи можна розглядати поточну ситуацію, що сприймається і аналізується системою. Результатом реакції системи стає зміна зовнішньої ситуації, і поведінка системи коригується в залежності від того, бажаною чи небажаною $є$ ця зміна.

Можна стверджувати, що здатність до поповнення первинних знань, є однією із ключових рис інтелектуальних систем. Ця властивість інтелектуальних систем називається здатністю до навчання. Розрізняють зовнішнє навчання та самонавчання.

Таким чином, інтелектуальною системою можна називати самокеровану кібернетичну систему, яка має певну суму знань про світ і здатна на основі безпосереднього сприйняття і подальшого аналізу поточної ситуації до планування дій, спрямованих на досягнення мети, а також до навчання.

Функціонування інтелектуальної системи можна описати як постійне прийняття рішень на основі аналізу поточних ситуацій для досягнення певної мети. Схема функціонування інтелектуальної системи наведена на рис. 1.

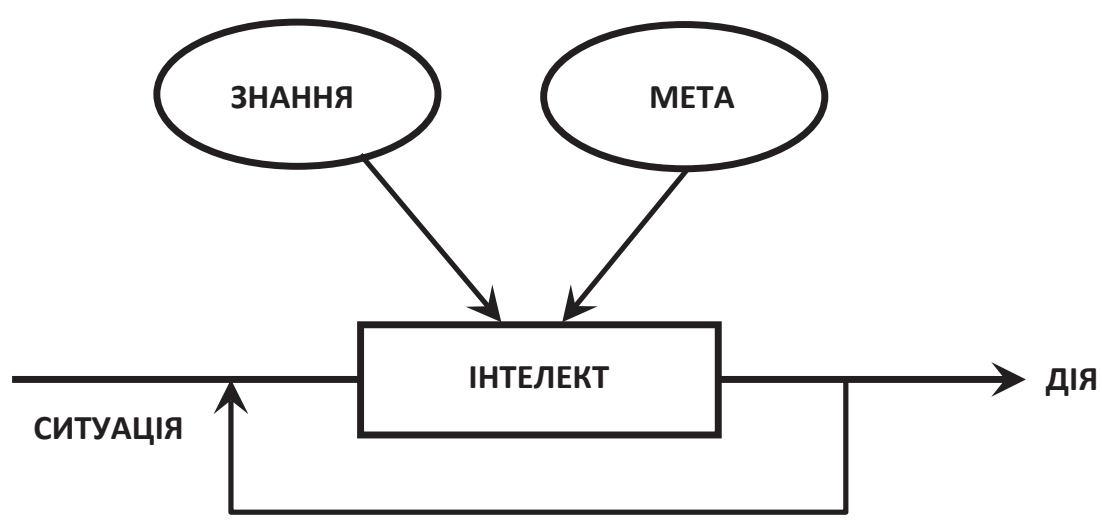

Рис. 1 - Схема функціонування інтелектуальної системи

Інтелектуальні системи здатні вирішувати завдання не лише за заданим алгоритмом, але й за побудовою завдання, навіть якщо воно не чітко сформульовано; вони здатні створювати нові алгоритми і навчатись, вдосконалюючи тим самим свої можливості.

Ці характеристики є актуальними в умовах вирішення таких завдань, які характеризуються наявністю великих масивів інформації, іiі неоднорідністю, неповнотою та розпорошеністю. 
На відміну від головного мозку людини, де одночасно функціонують мільйони нейронів, які забезпечують паралельну обробку великих масивів різнорідної інформації, в інтелектуальних машинах інформація передається односторонньо.

Тому в основу роботи вчених лягло прагнення створити прототип штучного інтелекту за допомогою нанотехнологій, що дозволить машині працювати подібно клітинам головного мозку - одночасно зчитуючи та обробляючи інформацію в різних напрямках.

Іншими словами, робот зможе приймати рішення в незнайомій ситуації, яка не описана в його програмі, на основі того, що він пережив в минулому, використовуючи знання, отримані в процесі навчання, за аналогією до життя людини [8].

У науковому співтоваристві виникло питання: які межі можливостей комп'ютерів і чи досягнуть машини рівня розвитку людини? Відповідь на це питання тісно пов'язане з поняттям рівня інтелекту. Однією $з$ класичних оцінок інтелектуальності машини є тест, запропонований відомим англійським ученим Аланом Тьюрингом, опублікований ним в 1950 році.

Даний метод має ряд важливих переваг: дає об'єктивне і чітке поняття про інтелект, виключає упередженість на користь живих істот. Однак деякі дослідники виступають проти подібного способу вимірювання інтелекту, аргументуючи свою думку в першу чергу тим, що машинний інтелект може настільки відрізнятися від людського, що перевіряти його людськими критеріями буде фундаментальною помилкою. Проте, тест Тьюринга $є$ важливою складовою в тестуванні та атестації сучасних інтелектуальних програм.

Окремо варто відзначити програмні засоби. До них в першу чергу відносяться експертні системи і системи розпізнавання образів. Експертні системи можуть втілювати в собі величезні обсяги знань і навичок, притаманних експерту-людині або групі фахівців. Ці системи, навіть з властивими їм обмеженнями, становлять велику цінність, зокрема, в геології, у медичній діагностиці, а також в деяких інших областях.

Особливе місце АІ-системи займають в хімічній промисловості. Їх застосовують для ідентифікації структур молекул по досвідченим даним, прогнозування реакційної здатності і фізичних властивостей хімічних сполук, планування складного синтезу, планування складних фізико-хімічний експериментів. Завдяки AI-технологій стала можливою автоматизована діагностика передаварійних станів обладнання, що дозволяє забезпечити надійність і безпеку хімічних виробництв. Так само широко використовуються пакети прикладних програм, що дозволяють знайти рішення деяких творчих завдань проектування хімічних виробництв. Інтелектуальні системи допомагають при плануванні роботи в складних ситуаціях, наприклад, складання графіків функціонування і циклограм хімікотехнологічних систем і складально-конвеєрних ліній [2], [5].

Виділяють два напрямки розвитку АI:

- спадний (семіотичний) - створення експертних систем, систем логічного висновку і баз знань, що імітують високорівневі психічні процеси (мислення, міркування, емоції, мова, творчість);

- висхідний (біологічний) - вивчення нейронних мереж і еволюційних обчислень, що моделюють інтелектуальну поведінку на основі біологічних елементів, а також створення біокомп'ютеру або нейрокомп'ютеру [4]. Основні напрямки штучного інтелекту представлені на рис. 2.

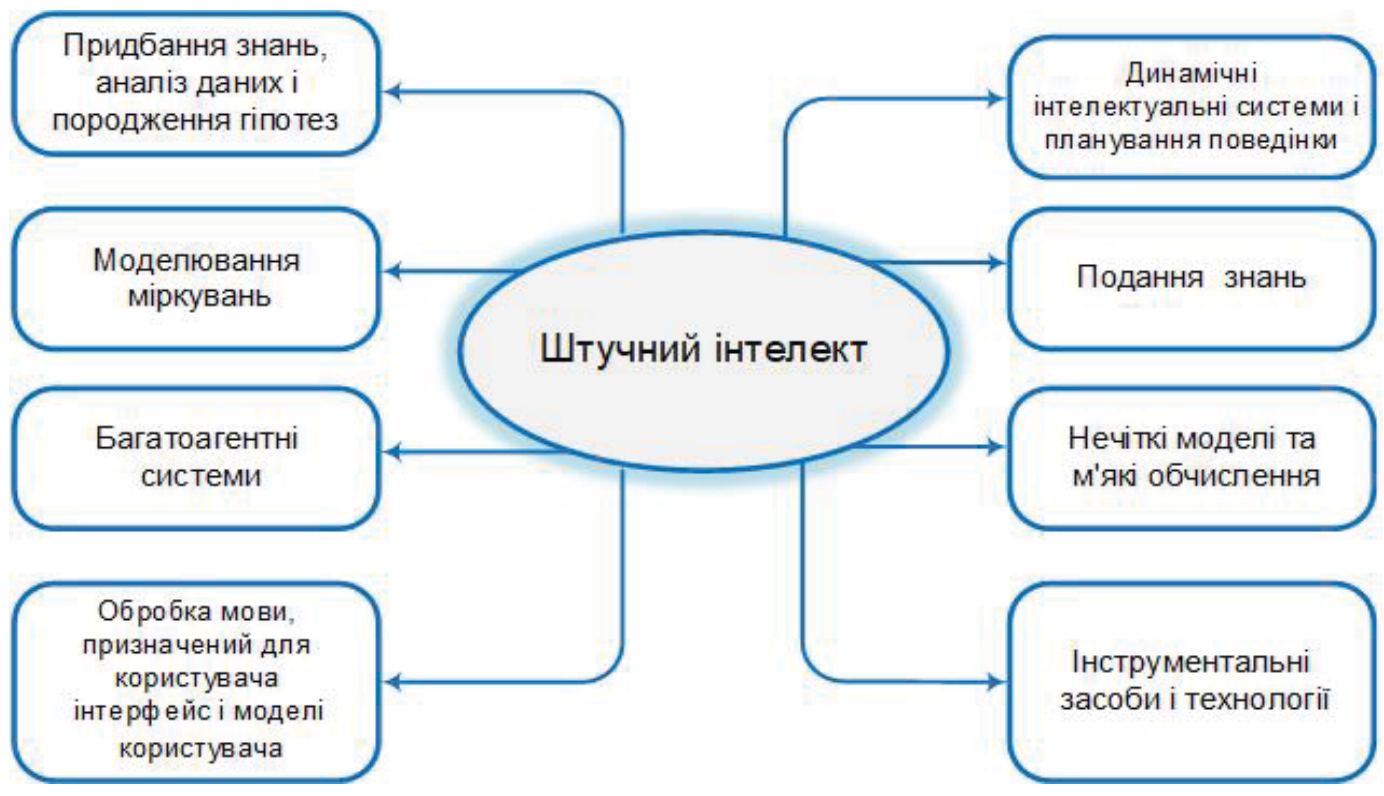

Рис. 2 - Напрямки ШІ 
http://www.atbp.onaft.edu.ua/

Найбільш перспективними на сьогоднішній день напрямками в пізнанні Ш, є нейронні мережі, еволюційні обчислення, експертні системи.

Нейронні мережі здатні вирішувати такі прикладні задачі, як: фінансове прогнозування, контроль за діяльністю мереж, шифрування даних, діагностика систем. В останні роки триває посилений пошук ефективних методів роботи нейронних мереж на паралельних пристроях [3].

На розвиток сфери еволюційних обчислень (ЕО) значний вплив зробили інвестиції в нанотехнології. Еволюційні обчислення покликані вирішити практичні проблеми самозборки, самовідновлення і самоконфігурірованія систем, що складаються з безлічі одночасно функціонуючих вузлів.

Попит на експертні системи залишається на досить високому рівні. Найбільшу увагу сьогодні залучено до систем прийняття рішень в масштабі часу, близькому до реального, системам динамічного планування, засобів зберігання, вилучення, аналізу та моделювання знань [1].

Експертні системи акумулюють знання експертів - провідних спеціалістів у даній предметній галузі. В основі роботи експертних систем лежить дедуктивне виведення нових тверджень 3 існуючих. Типове застосування експертних систем - консультації для фахівців середньої кваліфікації і неспеціалістів у тій галузі, для якої вона розроблена.

Відомо, що сучасний етап розвитку інформатики характеризується еволюцією моделей даних у напрямі переходу від традиційних (реляційна, ієрархічна, мережева) до моделей знань. Знання, як будь-яку інформацію, можна вважати даними. Іншим принциповим аспектом є те, що інформаційні системи, які грунтуються на знаннях, повинні мати можливість отримувати нові знання на основі існуючих.

Сьогодні штучний інтелект і машинне навчання стали застосовуватися практично у всіх сферах діяльності людей.

Наприклад, один з таких суперкомп'ютерів IBM Watson вже сьогодні розробляє 13 варіантів стратегії лікування раку різних локалізацій. Його особливістю є штучний інтелект з підтримкою запитань-відповідей системи. Завдяки доступу до 4 Терабайт (Тб) різної неструктурованою інформації, комп'ютер може розуміти і обробляти питання на природному для людини мовою і точно також давати на них відповідь.

Весь обчислювальний блок складається з 90 серверів IBM p750, побудованих на базі процесора POWER7, a загальний обсяг доступної для роботи оперативної пам'яті становить трохи більше 15 Тб. Незважаючи на такі вражаючі технічні характеристики, обчислювальна система не є найбільш передовою в світі, але на тлі конкурентів перевагою Уотсона є можливість роботи з когнітивними обчисленнями. Завдяки цьому, в майбутньому, на комп'ютер можна буде повністю покласти роботу з логістичними, транспортними, фінансовими і медичними завданнями.

Когнітивні обчислення мають на увазі під собою симуляцію людської мозкової діяльності. У теорії, якщо системи штучного інтелекту стануть централізованими, то цілком можливо, що машини зможуть обробляти інформацію, пізнавати світ і аналізувати події, що відбуваються подібно людям, можливо навіть більш продуктивно.

Штучний інтелект компанії FDNA вміє визначати вроджені хвороби і генетичні відхилення по фото. Протестувати можливості системи може кожен. Для цього потрібно встановити спеціальний додаток - Face2Gene, доступне для пристроїв на Android i iOS. Як запевняють розробники, програма вже зараз вміє визначати близько трьох 3 половиною тисяч генетичних захворювань, навіть якщо вони ще не проявили себе.

Неймовірно, але вже в наш час штучний інтелект приносить величезну користь, а також має вагомий потенціал у розвитку і розширенні діапазону сфер його застосування.

Крім фінансових операцій і медичних досліджень, в якості експерименту, до 2021 року компанією LG буде побудований завод, в якому обов'язки моніторингу зносу обладнання, а також процесів 3 перевірки виконання ділового плану буде довірено комп'ютерному помічникові. Крім того, закупівля потрібних комплектуючих, витратних матеріалів, а також відвантаження готової продукції буде здійснюватися управлінською системою штучного інтелекту.

Поширення комп'ютерних мереж і створення високопродуктивних кластерів викликали інтерес до питань розподілених обчислень - балансуванню ресурсів, оптимальному завантаженні процесорів, самоконфігуруванню пристроїв на максимальну ефективність, відстеження елементів, що вимагають оновлення, виявлення невідповідностей між об'єктами мережі, діагностування коректної роботи програм, моделювання подібних систем.

Традиційно високий інтерес до Ш в середовищі розробників ігор і розважальних програм. Серед нових напрямків їх досліджень - моделювання соціальної поведінки, спілкування, людських емоцій, творчості.

Німецька дослідницька компанія IPlytics з'ясувала, хто з компаній лідирує в галузі штучного інтелекту (AI), яку визнано найбільш швидкозростаючою сферою за кількістю зареєстрованих патентів (табл. 1). 
Таблиця 1 - Топ 5 компаній-лідерів в галузі АІ за кількістю заресстрованих патентів станом на січень 2019 року

\begin{tabular}{|l|c|c|}
\hline \multicolumn{1}{|c|}{ Назва компанії } & Місце & Кількість запатентованих \\
& & АІ-технологій \\
\hline Корпорація Microsoft (за даними DailyComm) & 1 & 18365 \\
\hline IBM & 2 & 15046 \\
\hline Південнокорейська Samsung & 3 & 11243 \\
\hline Американська компанія Qualcomm & 4 & 10178 \\
\hline Google & 5 & 9536 \\
\hline
\end{tabular}

Фахівці підрахували, що загальна кількість патентів в сфері штучного інтелекту за 10 років збільшилася більш ніж утричі - з 22913 в 2008-му до 78085 в 2018-му.

Цьому сприяють інвестиції в АI стартапи, які виросли на 21\%. Згідно зі спільним звітом PWC i CBInsights, інвестування АІ-стартапів склало близько 2,3 млрд. доларів (рис. 3).

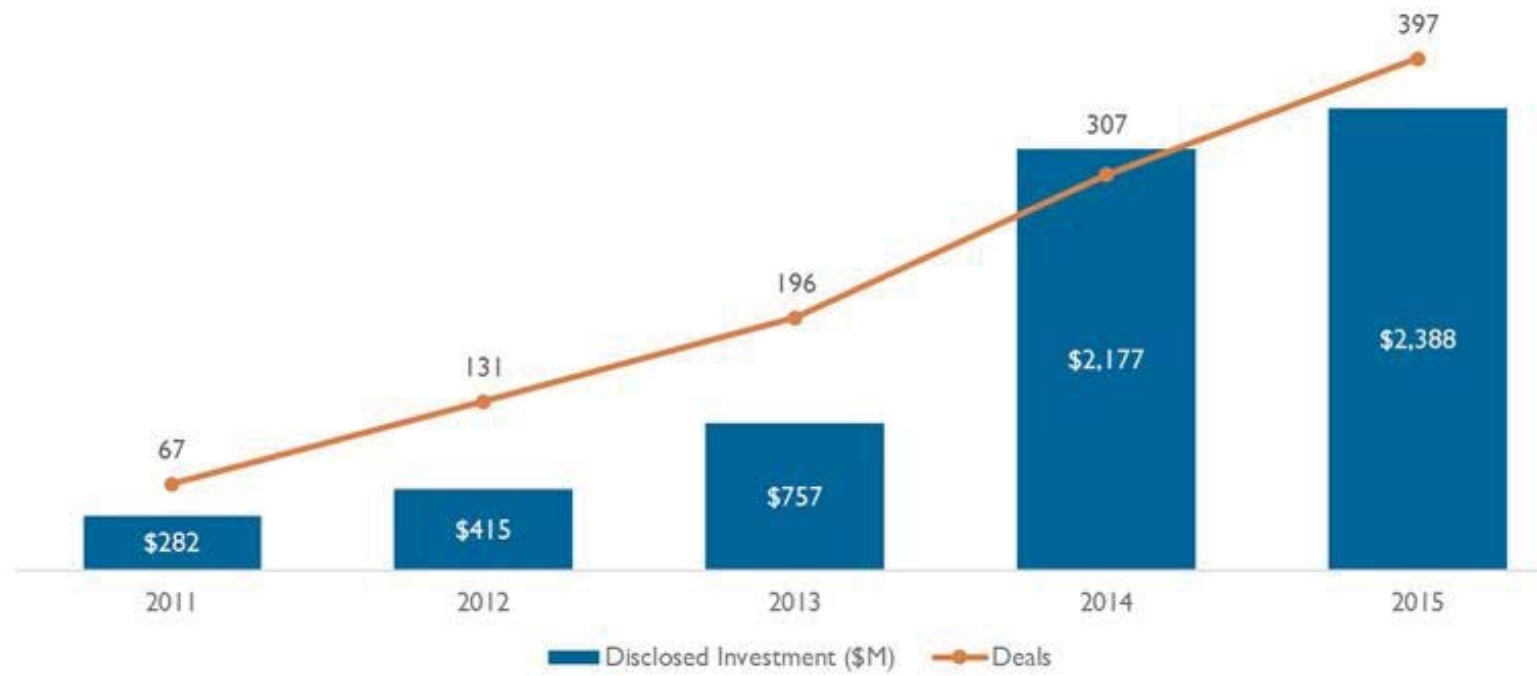

Рис. 3 - Щорічне інвестування АІ-стартапів і їх кількість у 2011-2015 рp.

За даними Artificial Intelligence Industry in Eastern Europe 2018, який опублікувала компанія Deep Knowledge Analytics, Україна увійшла до трійки лідерів за кількістю компаній, що працюють у сфері штучного інтелекту в Східній Європі. За даними компанії, в Україні зараз 57 компаній, які працюють у сфері штучного інтелекту. Україна також лідирує по всій Європі за кількістю аутсорсинг-компаній в галузі штучного інтелекту. Таких у країні 26, а у всьому світі - 226.

За даними LinkedIn, в Україні понад 2000 компаній, які займаються розробками у сфері штучного інтелекту, більшість з них працює над програмним забезпеченням (38\%), серед інших популярних напрямків - інформаційні технології, чат-боти, асистенти та розважальні продукти.

Висновки

Основний фактор, що визначає сьогодні розвиток АІ-технологій - це зростання продуктивності сучасних комп'ютерів в поєднанні із підвищенням якості алгоритмів, які дозволять розробляти системи, не зовнішньо схожі на людину, а діючі, як людина.

Вчені намагаються заглянути в більш віддалене майбутнє: чи здатна наука створити відповідні алгоритми? Чи зможемо контролювати такі машини? Відповідей на ці питання поки що немає. 
Сфера штучного інтелекту розвивається поступово. Тому результати досить добре прогнозовані, хоча на цьому шляху не виключені і прориви. Такі ініціативи будуть з'являтися на стиках різних математичних дисциплін - теорії ймовірності, нейронних мереж, нечіткої логіки.

\section{Список використаних джерел}

[1]Анісімов, А. В. Природомовна інформатика / А. В. Анісімов // Стан та перспективи розвитку інформатики в Україні. - К.: Наукова думка, 2010. - С. 541-547.

[2] Винцюк, Т. К. Анализ, распознавание и интерпретация речевых сигналов / Т. К. Винцюк. - К.: Наукова думка, 1987. $-264 \mathrm{c}$.

[3] Вінцюк, Т. К. Автоматичне розпізнавання, розуміння та синтез мовленнєвих сигналів / Т. К.Вінцюк // Стан та перспективи розвитку інформатики в Україні. - К.: Наукова думка, 2010. - С. 529-541.

[4] Гаррисон, Г. Выбор по Тьюрингу / Г. Гаррисон. - 2008. - 308 с.

[5] Журнал «Інформаційні технології. Аналітичні матеріали». - 2008. - № 8. - С. 21-26.

[6] Системи штучного інтелекту: [навч. посіб.] / Ю. В. Нікольський, В.В. Пасічник, Ю.М. Щербина - Львів: Магнолія 2006, 2015. - 279 с.

[7] Сухоручкіна, О. М. Інформаційне забезпечення інтелектуалізованих робототехнічних комплексів / О. М. Сухоручкіна // Стан та перспективи розвитку інформатики в Україні. - К.: Наукова думка, 2010. - С. $547-561$.

[8] Шевченко, А. І. Світові тенденції та практичні досягнення у проблемі штучного інтелекту / А. I. Шевченко // Стан та перспективи розвитку інформатики в Україні. - К.: Наукова думка, 2010. - С. 561-572.

[9] Шлезінгер, М. І. Розпізнання образів / М. І. Шлезінгер // Стан та перспективи розвитку інформатики в Україні. - К.: Наукова думка, 2010. - С. 523-529.

[10] Ясницкий, Л. Искусственный интеллект / Л. Ясницкий. - «Информатика». - №16. - 2009. - 176с.

[11]Инвестиции в искусственный интеллект бьют все рекорды: [Електроний pecypc]: https://dev.by/news/investitsii-viskusstvennyy-intellekt-byut-vse-rekordy.

\section{References}

[1] Anisimov, A. V. Prirodomovna informatyka / A. V. Anisimov // Stan ta perspektyvy rozvytku informatyky v Ukrayini. - K .: Naukova dumka, 2010, p. 541-547.

[2] Vintsyuk, T. K. Analiz, rozpiznavannya i interpretatsiya movnykh syhnaliv / T. K. Vintsyuk. - K .: Naukova dumka. P. 264, 1987.

[3] Vintsyuk, T. K. Avtomatychne rozpiznavannya, rozuminnya ta syntez movlennyevykh sihnaliv / T. K.Vintsyuk // Stan ta perspektyvy rozvytku informatyky v Ukrayini. - K .: Naukova dumka. P. 529-541, 2010.

[4] Harrison, H. Vybir po Tyurynhu / H. Harrison. P. 308, 2008.

[5] Zhurnal «Informatsiyni tekhnolohiyi. Analitychni materialy ». - 2008. - № 8. - S. 21-26.

[6] Systemy shtuchnoho intelektu: navch. posib. / YU. V. Nikolskiy, V.V. Pasichnyk, YU.M. Shcherbyna - L'viv: Mahnoliya 2006. P. 279, 2015.

[7] Sukhoruchkina, O. M. Informatsiyne zabezpechennya intelektualizovanikh robototekhnichnikh kompleksiv. Stan ta perspektyvy rozvytku informatyky v Ukrayini. - K .: Naukova dumka. P. 547-561, 2010.

[8] Shevchenko, A. I. Svitovi Tendentsiyi ta Praktychni Dosyahnennya u problemi shtuchnoho intelektu. Stan ta perspektyvy rozvytku informatyky v Ukrayini. - K .: Naukova dumka. P. 561-572, 2010.

[9] Shlezinher, M. I. Rozpiznannya obraziv. Stan ta perspektyvy rozvytku informatyky v Ukrayini. - K .: Naukova dumka. P. 523-529, 2010.

[10] Yasnytskyy, L. Shtuchnyy intelekt. «Informatyka». № 16. P. 176, 2009.

[11] Investytsiyi v shtuchnyy intelekt byut vsi rekordy: [Elektronyy resurs]: https://dev.by/news/investitsii-viskusstvennyy-intellekt-byut-vse-rekordy. 